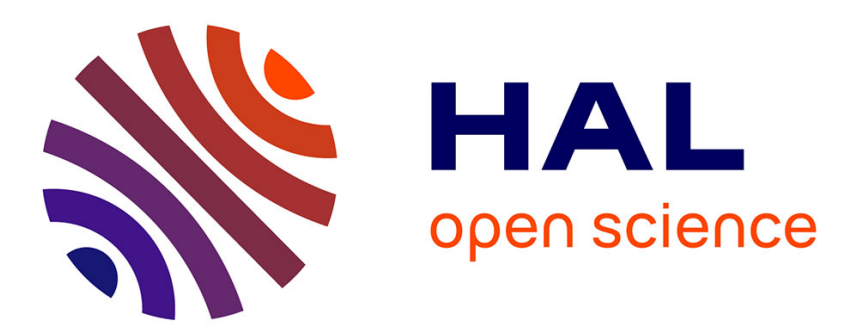

\title{
Treatment of pistachios with boric acid, Zn-sulfate and Zn-chelate
}

\author{
C. Tsipouridis, T. Thomidis, I. Zakinthinos, Z. Michailidis, T. Michailides
}

\section{To cite this version:}

C. Tsipouridis, T. Thomidis, I. Zakinthinos, Z. Michailidis, T. Michailides. Treatment of pistachios with boric acid, Zn-sulfate and Zn-chelate. Agronomy for Sustainable Development, 2005, 25 (3), pp.377-379. hal-00886255

\section{HAL Id: hal-00886255 https://hal.science/hal-00886255}

Submitted on 1 Jan 2005

HAL is a multi-disciplinary open access archive for the deposit and dissemination of scientific research documents, whether they are published or not. The documents may come from teaching and research institutions in France or abroad, or from public or private research centers.
L'archive ouverte pluridisciplinaire HAL, est destinée au dépôt et à la diffusion de documents scientifiques de niveau recherche, publiés ou non, émanant des établissements d'enseignement et de recherche français ou étrangers, des laboratoires publics ou privés. 


\title{
Treatment of pistachios with boric acid, Zn-sulfate and Zn-chelate
}

\author{
C. TSIPOURIDIS ${ }^{\mathrm{a}}$, T. THOMIDIS ${ }^{\mathrm{a} *}$, I. ZAKINTHINOS $^{\mathrm{b}}$, Z. MICHAILIDIS $^{\mathrm{c}}$, T. MichAILIDES $^{\mathrm{d}}$ \\ ${ }^{\text {a }}$ Pomology Institute Naoussa, S.S. Naoussas 38, 59200, Imathia, Greece \\ $\mathrm{b}$ Technological Education Institute of Kalamata, Antikalamos 24100, Greece \\ ${ }^{\mathrm{c}}$ Technological Education Institute of Thessaloniki, P.O. Box, 57400, Thessoloniki, Greece \\ ${ }^{\mathrm{d}}$ University of California, Department of Plant Pathology, Kearney Agricultural Center, 9240 S, Riverbend Avenue, Parlier, California 93648, USA
}

(Accepted 14 April 2005)

\begin{abstract}
We studied the effect of boric acid, Zn-sulfate and Zn-chelate on shell split and development of fruit rot diseases of the pistachio cultivar Eginis. The results showed that boric acid applied to soil and leaves together gave the highest percentage of shell split. Boric acid applied solely to the soil also increased significantly the percentage of shell split. In contrast, Zn-sulfate and Zn-chelate did not affect shell splitting, regardless of treatment No rotten fruit was found in any of the treatments, including the control.
\end{abstract}

boron / Eginis / shell split / pistachio / zinc

\section{INTRODUCTION}

Pistachio is a deciduous, subtropical tree requiring winter chilling for good fruit production. Pistachio nuts are harvested in late September to early October when the hull separated from the shells and shell splitting reached a maximum. However, a small proportion of the nuts have their hulls and shells split along the suture (called early split nuts) exposing the kernel to infection by pathogens, such as Aspergillus flavus and A. parasiticus, which can produce aflatoxins in infected tissues, and infestation by insect attack (Doster and Michailides, 1995a, b). The cause of early splitting is unclear but factors such as high crop load and early-season irrigation deficit (stress) increases the incidence of early split nuts (Doster et al., 2001; Teviotdale et al., 2002).

In Greece, boron and zinc deficiencies are a major problem in pistachio orchards and remedial applications of boric acid, $\mathrm{Zn}$-sulfate and $\mathrm{Zn}$-chelate are common grower practices. However, whether nutrient status of pistachio trees affects the incidence of early split nuts has not investigated. The aim of this study was to test possible influence of boric acid, Zn-sulfate, and $\mathrm{Zn}$-chelate on early splitting along with the possibility that these applications promoted the development of fruit rot.

\section{MATERIALS AND METHODS}

The experiments were conducted in two consecutive years at the Pomology Institute, Naoussa (NAGREF) where a pista- chio orchard of the variety Eginis, grafted on a wild rootstock (Pistacia sp.), was established in 1986, spaced at $5 \times 5 \mathrm{~m}$ (40 trees/1000 sq. meters). Trees were irrigated by flooding (furrow irrigation) five to six times yearly. Trees were sprayed with a Bordeaux mixture at leaf fall stage, chlorothalonil at bloom and at 4 week intervals afterwards, and phosmet applied in both May and June. Nitrogen was applied as (NH4)2SO4 at $1 \mathrm{~N}$ units per tree. Visual inspection showed that the trees in the orchard had similar vigour and foliar condition.

The experimental design was completely randomized with 7 treatments: (a) boric acid (Borakas, 36.4\% B, Geolix EPE) applied as granules to the soil in November (100 g/tree); (b) boric acid applied to the soil as in treatment 2 and to leaves (5\%o aqueous solution, 4 liters per tree) at bloom, and repeated 15 days later; (c) Zinc-chelate (Zn-sequestrene, $5 \% \mathrm{Zn}$, Geovet Hellas) applied to the soil (100 g/tree in 10 liters aqueous solution) in April; (d) Zn-chelate applied to both soil (100 g/tree in 5 liters aqueous solution) and leaves ( $20 \mathrm{~g} /$ tree in 10 liters aqueous solution) before the first growth flush has hardened; (e) Znsulfate (Zinc Sulfate, 36\% Zn, Euthimiadis A.E.) applied as granules to the soil (200 g/tree) in February; (f) Zn-sulfate applied to the soil as in treatment 6 in February and to leaves (6\% aqueous solution, 10 liters per tree) in October and again in February. Untreated trees were used as control.

There were 3 replicates of 3 adjacent trees for each treatment. Fifty fruits were collected arbitrarily throughout the canopy from each tree and the percentages of shell splitting and infection by fruit rot diseases were determined. All experiments

* Corresponding author: thomi-1@otenet.gr 
Table I. Foliage analyses for the pistachio orchard before treatment.

Treatments

\begin{tabular}{cccccccccccccc}
\hline $\mathrm{H}_{2} \mathrm{BO}_{3} \mathrm{~S}^{\mathrm{a}}+\mathrm{L}^{\mathrm{a}}$ & \multicolumn{2}{c}{$\mathrm{H}_{2} \mathrm{BO}_{3} \mathrm{~S}$} & \multicolumn{2}{c}{$\mathrm{Zn}$-sulfate S } & \multicolumn{2}{c}{$\mathrm{Zn}$-sulfate $\mathrm{S}+\mathrm{L}$} & \multicolumn{2}{c}{ Zn-chelate S + L } & \multicolumn{2}{c}{ Zn-chelate S } & \multicolumn{2}{c}{ Untreated Control } \\
\hline $\mathrm{Zn}$ & $\mathrm{B}$ & $\mathrm{Zn}$ & $\mathrm{B}$ & $\mathrm{Zn}$ & $\mathrm{B}$ & $\mathrm{Zn}$ & $\mathrm{B}$ & $\mathrm{Zn}$ & $\mathrm{B}$ & $\mathrm{Zn}$ & $\mathrm{B}$ & $\mathrm{Zn}$ & $\mathrm{B}$ \\
10.5 & 22.1 & 10.2 & 21 & 12.7 & 20.1 & 12.5 & 19.6 & 12.9 & 19.7 & 12.4 & 19.9 & 10.1 & 19.5 \\
\hline
\end{tabular}

a. $\mathrm{S}=$ soil application, $\mathrm{L}=$ foliar application.

were conducted for two consecutive years. Results were similar according to the Bartlett's test of homogeneity of variance so data were combined and treatment means were separated by using Duncan's Multiple Range Test at $P=0.05$.

Fifty randomly selected leaves per replicated tree for each treatment were collected (around the tree canopy at a height of approximately $1.5 \mathrm{~m}$ ) early in the morning, put into plastic bags and transferred to the laboratory for mineral measurements.

The methods used for the analysis of soil and leaves for mineral content were: atomic absorption spectroscopy for Fe, Mn, $\mathrm{Zn}, \mathrm{Cu}$; molybdophosphoric blue colour for P; flame photometer for K; E.D.T.A. titration for $\mathrm{Ca}$ and $\mathrm{Mg}$; curcumine for B. The leaves were firstly cleaned with wash powder (Tide, $2 \%$ ), then washed with tap water and finally with distilled water. Soil was alkaline $(\mathrm{pH}=7.9)$ and calcareous (active lime $=9.68 \%)$ containing B and $\mathrm{Zn}$ at a level of 30.4 and $4.76 \mathrm{mg} / \mathrm{L}$, respectively. Leaf analysis was presented in Table I.

\section{RESULTS AND DISCUSSION}

Among the various treatments, boric acid applied either to the soil or leaves resulted in the highest percentage of shell split (Fig. 1). According to Brown and Hu (1996), foliar-applied boron is translocated from the treated leaves of sorbitol-rich species, such as pistachio, to adjacent fruit, specifically to the fruit tissues (hull, shell, or kernel). Boric acid applied to the soil only also increased significantly the percentage of shell split compared to the untreated control. Although soil and foliar applications with $\mathrm{Zn}$-sulfate and $\mathrm{Zn}$-chelate relatively increased the leaf $\mathrm{Zn}$ concentration, they did not affect the percentage of shell splitting (Fig. 1). Probably, zinc does not play an important role to shell splitting of pistachio. This may result from the limited mobility of applied Zn, which has been attributed, at least in part, to the high binding capacity of leaf tissue for Zn (Zhang and Brown, 1999a). Zhang and Brown (1999b) reported that pistachio leaves retained $12 \%$ of the total $\mathrm{Zn}$ applied, with approximately half of it subsequently translocated away from the treated area. No foliar symptoms of boron toxicity were observed in our investigation

No conclusions can be draw on the effects of boric acid and $\mathrm{Zn}$-sulfate and $\mathrm{Zn}$-chelate on infection of early splits by fungi or insects since no rotten fruit was found in any of the nuts harvested from the treated and the control trees. Doster and Michailides, (1995a, b, 1999) found that nuts showing early

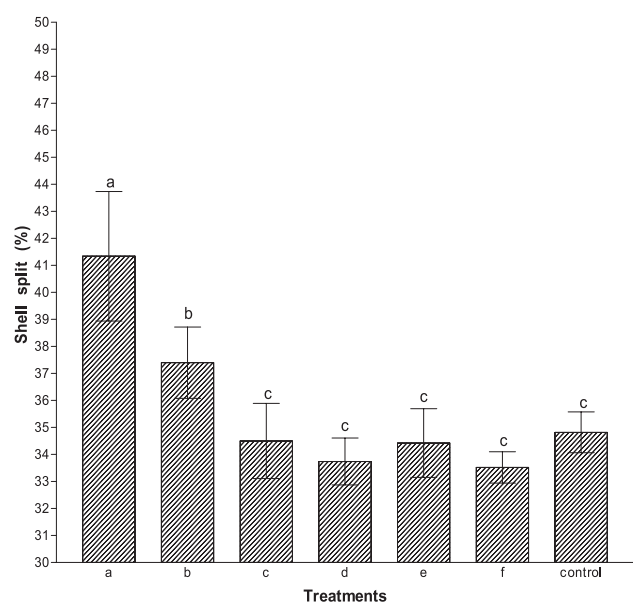

Figure 1. Effect of boric acid, Zn-sulfate and Zn-chelate as soil and foliar applications on the percentage of shell split of pistachio fruits $(a=\mathrm{H} 2 \mathrm{BO} 3$ soil and foliar application, $b=\mathrm{H} 2 \mathrm{BO} 3$ soil application, $\mathrm{c}=\mathrm{Zn}$-sulfate soil and foliar application, $\mathrm{d}=\mathrm{Zn}$-sulfate soil application, $\mathrm{e}=\mathrm{Zn}$-chelate soil and foliar application, $\mathrm{f}=\mathrm{Zn}$-chelate soil application).

hull split had more aflatoxin, moldy kernels, and insect infestation than those which have their hulls not split or split later in the season. They (Doster and Michailides, 1995a, b, 1999) examined each nut with a microscope to observe mycelia and sporulation of the fungi that colonize the nuts, and frass from infestation by navel orangeworm (Transitella amyloides). We, however, did not use a microscope in this study, instead the nuts were examined macroscopically.

\section{CONCLUSION}

Generally this study indicated that boron should be considered as a contributory factor responsible, at least partly, for early split nuts. The consequences of heavy boron applications to pistachio could be the reduction of fruit quality from early shell split, leading to economic losses. The results suggest that growers should be cautious when apply boron to pistachio crops as either a foliar or soil treatment. 


\section{REFERENCES}

Brown P., Hu H. (1996) Phloem mobility of boron is species dependent: Evidence for phloem mobility in sorbitol-rich species, Ann. Bot. London 77, 497-505.

Doster M., Michailides T. (1995a) The relationship between date of hull splitting and decay of pistachio nuts by Aspergillus species, Plant Dis. 79, 766-769.

Doster M., Michailides T. (1995b) The development of early split pistachio nuts and their contamination by molds, aflatoxins, and insects, Acta Hortic. 415, 359-364.
Doster M., Michailides T. (1999) Relationship between shell discoloration of pistachio nuts and incidence of fungal decay and insect infestation, Plant Dis. 83, 259-264.

Doster M., Michailides T., Goldhamer D., Morgan D. (2001) Insufficient spring irrigation increases abnormal splitting of pistachio nuts, Calif. Agric. 55, 28-31.

Teviotdale B., Michailides T., Pscheidt J. (2002) Compendium of nut crop diseases in temperate zones, The American Phytopathological Society, St. Paul, Minnesota, USA, pp. 64-65.

Zhang Q., Brown P. (1999a) Distribution and transport of foliar applied zinc in pistachio, J. Am. Soc. Hortic. Sci. 124, 433-436.

Zhang Q., Brown P. (1999b) The mechanism of foliar zinc absorption in pistachio and walnut, J. Am. Soc. Hortic. Sci. 124, 312-317.

To access this journal online: www.edpsciences.org 